who desires to take up the more applied side of the profession, the works apprentice who has attained a sufficiently high standard in theoretical study, and possibly senior men from the industry and the Forces who desire refresher courses.

\section{A Programme for the Royal Society of Arts}

Dr. E. F. Armstrong's inaugural address to the Royal Society of Arts on November 3 entitled "The Long Road of Progress" reviewed briefly the general trend of the Society's activities since its foundation in 1754 , commenting on the number of the older societies which regard the Royal Society of Arts as a foster parent. While it is no longer the tradition that the first popular account of any discovery or invention is given to the Society, that tradition is always prominently before the Society in arranging its programme. Discussing the future, Dr. Armstrong urged that the Society should help to form public opinion on housing, on nutrition, and other subjects, through the medium of its members and their friends in a way that the Press, which to-day is largely political and seldom practical, can never do. In addition to lectures, however, it could pursue such projects as raising the artistic standard of the nation, as through its institution of the award Royal Designer for Industry, and its recommendations as to the best training for students intending to design for industry and in art schools in general, and the best methods of selection of young persons for such work.

After a reference to education and to the value of the examinations of the Royal Society of Arts, Dr. Armstrong touched on the question of research and the necessity of having the right kind of men to carry it out efficiently, and the importance of providing the proper facilities. Factories, he emphasized, are worth as much as the ability that directs them and no more, and even in research the head of the department must understand the art of managing men and be able to get along with them and to think as they think. A research department should be changing all the time, so as to bring in young men with ideas. Finally, popular interest in science must not only be maintained, but even increased, if we are to hold our own in the years to come. Whether carried on with Government support or in endowed institutions of learning, the full development of our scientific potentialities depends upon the appreciation of the public. This means continually providing the public with impersonal news regarding scientific progress in all lines of interest to them, from both the material and the philosophical points of view. Moreover, the biggest fight in the post-war world is likely to be for individuality. Science needs tolerance, freedom from restraint and a recognition of the value of individuality, and because it has freed men's minds and helped to free man's soul by broadening the basis of religion, it is regarded by some as the great hope of mankind. We must learn the facts about the environment in which we live if we wish to adjust ourselves harmoniously with it.

\section{Astronomical Work in the U.S.S.R.}

SoME information about astronomical activities in the U.S.S.R. has been received from Alexander Orlov, formerly director of the Odessa Observatory and now director of the Poltava Observatory, which was built in 1926 for the study of latitude variation and the movements of the earth's pole. When the
Germans were approaching Poltava, the valuable equipment of the Observatory was removed to Irkutsk in Siberia, to save it from the destruction that had overtaken the Pulkovo Observatory, near Leningrad. When the Red Army liberated Poltava, M. Orlov returned there, passing through Kharkov en route. In Kharkov all the main buildings and cultural institutions were in ruins ; of the staff of the Kharkov Observatory, who had not succeeded in escaping before the Germans arrived, some had been killed, some had died of hunger, some were missing and the few who survived were in a deplorable condition. In once flourishing districts of the Ukraine everything had been burnt or destroyed. The city of Poltava had been destroyed with deliberate thoroughness; it had been surrounded and nobody allowed to leave. The Poltava Observatory was damaged, but by chance had escaped destruction. The Ukrainian Government has decided to restore the Observatory as quickly as possible; funds for this purpose, and for a considerable extension of the work of the Observatory, are being assigned. During the past session of the Academy of Sciences of the U.S.S.R. it was decided to open another observatory for latitude-variation work at Komosomlsk, in the same latitude as Poltava. It was also planned to create a central observatory near Kiev, for fundamental observations, analogous to the Pulkovo Observatorv.

\section{Functions of the Special and General Libraries}

Mr. G. Woledge, librarian of the Queen's University, Belfast, has directed attention, in a letter to the Editors, to a conflict of interests between the small special library and the large general library, which appears to be suggested by the discussions at the ASLIB Conference last September on the international rehabilitation of special library services. Mr. E. J. Carter's paper on the "Rehabilitation Problem and the Service and Technique of Special Libraries and Information Bureaux" and Mr. F. C. Francis's paper on "The British Museum as a Special Library" indicate, indeed, though without explicitly stating so, that the two types are complementary, not competitive, and quite apart from questions of co-operation involved in distribution and dispersion, it is clear both from Mr. McColvin's report on public library service and the more recent statement issued by the Council of the Library Association that the position of special libraries and reference libraries in the general lending library service of Great Britain is receiving attention.

Mr. Woledge acknowledges the immense contribution to research which has been made by the system of inter-library lending through the National Central Library; but points out that there are as yet no accepted principles by which we can determine the complicated question of the desirable minimum of book-resources for the country's research work. Leaving aside altogether the question of the duplication of the most important books-those of which many copies may be in use at the same time in different places and those which are indispensable in any scientific man's library--it is not enough to have only one copy of each book which may be wanted or only one collection for each subject. While the special library has a better chance of completing its collection of the more elusive kinds of literature and can be organized from one exclusive point of view with a specialist and expert staff, the staff of a general library also has its rather different but characteristic 
expert knowledge, and in so far as it is prevented from specializing is saved from onesidedness. Even from the point of view of research we need general libraries, highly specialized libraries and intermediate collections; libraries from which books can be borrowed and those from which they cannot. The most desirable lines for their development can only be decided after careful examination, subject by subject, of the needs of those who use them. A general survey of Great Britain's needs would, as Mr. Woledge suggests, and has already been strongly recommended as an urgent need in the McColvin report, be of great value in helping to make the best use of available funds, and his warning that funds cannot be unlimited or expended extravagantly is timely. Mr. Woledge scarcely formulates the questions which must be answered before either large or small libraries can take the fullest part in a national system of providing books and information, but he shows that all engaged in library work should consider more closely their functions, not only in relation to special needs, but also to those of the nation as a whole and the contribution they are best equipped to make to national needs.

\section{Radiolocation and Shipping Risks in Peace-time}

The fifteenth report from the Select Committee on National Expenditure for the session 1942-43, dealing with the salvage of ships and cargoes, contains important references to developments in radiolocation which seem likely to reduce shipping casualties, and thus to decrease the amount of salvage work to be done in normal times. As a decision on the future use of the large quantity of radiolocation equipment owned by the Government is urgently required, evidence was heard from eminent scientific workers and from representatives of Trinity House on the possibility of using it to increase the safety of navigation after the War under conditions of low visibility. The Committee was assured that much of this equipment would be of value for such purposes, and accordingly it recommends that the Government should examine the question of the post-war use of radiolocation apparatus for safety at sea, together with the making of any international agreements required. The bulk of the report gives an interesting picture of the general salvage position in 1939 and during the War, which does not always reflect credit on the Admiralty. While the Committee resists the proposal to create a monopoly for British salvage enterprises in British territorial waters, unless the hopes of a general breakdown of monopolies and barriers to commercial activity are disappointed, it advances proposals for maintaining British salvage enterprises in so sound and efficient a state that underwriters will not be obliged to call on the services of foreign firms.

\section{The Royal Irish Academy}

THE meeting of the Royal Irish Academy on November 8 was devoted to a celebration of Hamilton's discovery of quaternions. A well-attended meeting which included $\mathrm{Mr}$. De Valera and other Ministers was addressed by the president, Dr. R. I. Best, who read messages from Prof. G. D. Birkhoff of Harvard and Prof. J. L. Synge of Ohio State University. An account of the Dublin mathematical school in the early nineteenth century with reference to the work not of Hamilton only but also of
McCullagh, Lloyd, Jellett, Haughton, Salmon, etc., was given by Prof. A. J. McConnell. Prof. A. W. Conway read a paper on quaternions and matrices in which he showed that the use of quaternion methods makes for great simplification of the meson matrices. A paper by Prof. E. T. Whitaker on the sequence of ideas in the discovery of quaternions and a note on quaternions by Prof. G. D. Birkhoff were also read. A paper by Rev. J. R. Colthurst on the Inconsian calculus of Sir William Rowan Hamilton was read in title. A communication from Prof. F. D. Murnaghan of Johns Hopkins University, entitled "A Modern Presentation of Quaternions", owing to postal delays was received too late for the meeting, but will be included in the report of the proceedings which will be printed.

\section{The Haffkine Institute, Bombay}

THE report for 1940-41 of the Haffkine Institute at Parel, Bombay, shows a record of widely useful work, of expansion of departments to meet the needs of the War and of increased production of sera, antitoxins and vaccines for the Forces. A new department for the manufacture on a large scale of antitoxins, toxoids and sera has been begun and the Institute has found that it can produce these at a cost one half to one sixth of that of the imported products. The Department of Chemotherapy is also new ; it reports that sulphathiazole is effective for the treatment of bubonic plague. Sulphonamide products are being synthesized, their commercial production is being investigated and new compounds in this series are being sought. The production of Haffkine's antiplague vaccine and other work on plague occupy, perhaps naturally, a considerable part of this report. But interesting work is also being done in an endeavour to replace the standard malarial remedies, the supply of which has been reduced by the War. It is claimed that sulphathiazole and another sulphonamide prepared by the Institute have remarkable curative effects on monkey malaria without the relapses which follow the treatment of monkeys with atebrin and quinine.

\section{Poliomyelitis in the United States}

According to official information, the incidence of this disease in July reached epidemic proportions in several south-western States, and the figures for the country during the first six and a half months were the highest in twelve years. Figures for the week ending July 17 showed 297 cases in the United States as compared with 245 for the preceding week ; 231 cases or 94 per cent were reported from three States, namely, Texas with 102, California with 90 and Oklahoma with 39 . For the first twenty-eight weeks of $1943,1,626$ cases were listed for the entire country.

\section{Islands and Peoples of the East Indies}

WAR Background Studies of the Smithsonian Institution, No. 14, relates the story of the East Indies and their inhabitants. The account does not pretend to be other than superficial, but for the intelligent reader wishing to know something about an area that may at any time now come to figure largely in the war news, this book can be confidently recommended. It contains a great deal of information and is beautifully illustrated. 